\title{
Research on formulation strategy of talent training plan for the construction of applied undergraduate first-class specialty
}

\author{
Guo-Ping Wang ${ }^{1, a,{ }^{,}, \text {Shuang Cheng }}{ }^{2, \mathrm{~b}}$ and Hua-Ning $\mathrm{Hao}^{3, \mathrm{c}}$ \\ 1,2,3 the High-Tech College of Xi'an University of Technology, Xi'an, 710109, China \\ a diaphragmcoupling@163.com, b814660333@qq.com, c562404230@qq.com
}

${ }^{*}$ Corresponding author

\begin{abstract}
Keywords: Teaching reform, New economy, Collaborative innovation, Applied specialty, Training program
\end{abstract}

\begin{abstract}
Aiming at new requirements for personnel training from the new economy, Strategies for developing new talents training program of first-class mechanical design and manufacturing and Automation specialty in application oriented Universities are researched. First of all, new characteristics of talent training program for application oriented professional construction are put forward to react the current higher education situation; secondly, the formulation strategy of talent training program with new characteristics and an example are presented; finally, the characteristics and logical relationship between the new strategy are expatiated.
\end{abstract}

\section{Introduction}

In November 2015, the State Council of China formally issued the overall plan for promoting the construction of world class universities and first-class disciplines, which aims at the national "two one hundred years" strategic objectives. It is another national key construction project in the field of higher education in China after the "985 Project" and "211 Project". In 2017, the national education conference confirmed that the double first class construction will start in 2017, and the double first class construction list will be announced in October. At the same time, in May 2017, the Department of higher education of the Ministry of education puts forward "new engineering research", and pointed out a number of problems oriented [1] and the publication of a new engineering research guide in September, which will further promote the deepening of the development of Engineering Education in China. At a time, these two are the programmatic documents of the development and discipline construction of various provinces and cities and colleges and universities. The local government education department has introduced the "double first-class" construction and the "new engineering" research program. The local finance also supports the two first-class and new engineering construction, with high enthusiasm and great participation. This plan and a guide will surely change the development ecology of China's higher education and accelerate the pace of building China's higher education power.

The construction of first-class universities is based on the construction of first-class disciplines. Universities without first-class disciplines will never become first-class universities. The construction of the discipline is centered on the training of talents, and The effectiveness of its construction is measured by the quality of trained talents. Therefore, the advantages and disadvantages of professional training programs will directly affect specialty construction and discipline development. The first task of cultivating excellent talents is to establish their ideal and belief, promote the physical and mental health, and understand the unity of knowledge and Practice. Then, according to serve the needs of economic and social development training applied talents with knowledgment skills and innovation ability. Therefore, the formulation or revision of the talent training program must embody the combination of "Virtue" and "talent" and keep pace with the times. This article mainly aims at the research of the new characteristics and the course setting strategy of the talent training program in the construction of the first-class professional engineering specialty. Organization of the text. 


\section{The new features of the formulation of the training program for the first class professionals}

\subsection{Innovation and enterprise education characteristics}

At the Davos forum in September 2014, Premier Li Keqiang put forward a mass innovation business. In June 2015, "the State Council's opinions on promoting several policies and measures for mass entrepreneurship and mass innovation" were published. The popular innovation of the public has become the current China's innovation driven strategy. Its theme is to promote entrepreneurship by innovation, to promote employment by entrepreneurship and to promote the new development of the economy. The main body of innovation and entrepreneurship is transformed from scientists and enterprises into the general public. In a knowledge-based society, students of higher education become the most innovative and entrepreneurial group in the general public. In 2017, the third China University student innovation and entrepreneurship competition put forward the idea of "promoting teaching through competition, and integrating competition and education" to promote the development of innovation and entrepreneurship. Therefore, the development of new talent training program must require students to fundamentally understand innovation and entrepreneurship, improve the awareness of innovation and entrepreneurship, and take the initiative to invest in the flood of innovation and entrepreneurship. Therefore, it is imperative to popularize knowledge of innovation and entrepreneurship education among all college students.

\subsection{Synergistic innovation ability}

The eighteenth people's Congress of the Communist Party of China has clearly proposed that scientific and technological innovation is the strategic support for improving the social productivity and comprehensive national strength, and is the core of the overall development of the country. In the following nineteenth meetings, In the following nineteenth meetings, the development strategy driven by innovation has been deployed to make innovation the first driving force for development of China's economy from high speed to high quality. Innovative consciousness education, innovative thinking method education and innovative practice education should be fully embodied in the talent training plan. In addition, the current industry is gradually transforming to highly intensive knowledge style. It is unrealistic for individuals to master all knowledge, and the strength of modern social innovation teams is particularly important. Therefore, in higher education, we should constantly cultivate students' basic innovation ability while paying attention to the cultivation of collaborative innovation ability.

\subsection{Discipline integration education}

Collaborative innovation should not only master this specialty, but also master other related professional knowledge. These related professional knowledge not only laid the foundation of independent research, but also became the link of collaborative innovation. At present, the deep integration of innovation and entrepreneurship, first of all, put forward higher requirements for the ability to cultivate professional innovation and design, not only to strengthen the traditional innovative design ability, but also to realize the deep integration of innovation and information technology. Secondly, it is necessary to master certain knowledge of business science and to make students better carry out the application of scientific and technological achievements and the transformation of productivity.

In February 2017, the Department of higher education of the Ministry of education, in order to deepen the reform of engineering education and promote the development of national innovation, has deployed the major strategies such as "one way", "China made 2025" and "Internet +", and issued a "notice on the development of new engineering research and practice" so as to make the training of higher education talents adapt to the new economy characterized by the new technology, new format, new model and new industry. Talent training pays more attention to the deep integration of engineering major, business science and information technology. Obviously, under the new situation of higher education, it is more urgent to foster cross disciplinary integration of talents training. 


\section{Implementation strategy of new professional talents training plan}

The general education of innovation and entrepreneurship focuses on making students understand the background and significance of double creation strategy, understand the meaning of innovation and entrepreneurship and the methods and processes of innovation and entrepreneurship. In the training program of professional talents, it is suggested to set up a general compulsory course "foundation and practice of innovation and entrepreneurship", which is divided into theoretical part and practice link, mainly for middle and high grade students, with competition as the practice link, to promote teaching, to test and improve the effect of learning in practice, and to achieve the integration of competition and education.

The characteristics of collaborative innovation should be reflected from the following aspects: first, through professional introduction and professional advanced technology courses or academic lectures to stimulate students' interest in learning, to cultivate students' scientific enthusiasm, to stimulate students' innovative pursuit and innovation consciousness. We can set up the elective course of scientific thinking method, stimulate the students' creative thinking by case teaching, collide the spark of wisdom, and explain the general steps and methods of scientific research for students systematically through the series of scientific research lectures, actively guide the undergraduates to put into the scientific research, and initially begin to participate in the publication of papers, patent applications and other scientific work. Third, pay attention to the cultivation of students' creative practice ability, set up a comprehensive design course and design type or innovative experiment, so that students can experience the fun of innovation and creation in the experiment. Fourth, in the creative practice, we should pay attention to cultivating the students' ability to innovate through teamwork, and to guide the students' consultation, orderly division of labor and team integration through the modular cohesive and interactive integration model of design or experiment.

Facing the new economic application features: the training of interdisciplinary integrated talents is mainly manifested in the organic setting and connection of the basic courses of information technology, the basic and directional routine special courses and the business courses. At the same time, in the daily teaching work, it pays more attention to the integration of information technology and teaching and learning, and active teaching reform is also a very critical factor. The employment oriented curriculum is aimed at the practical application of future jobs. It is necessary to set up a series of courses based on the actual working elements of different major graduates in their jobs. This requires a wide range of social investigation and feedback.

\section{Example}

Taking the specialty of mechanical design and manufacturing and automation as an example, in order to highlight the new characteristics of personnel training, the following courses are suggested:

The general education of innovation and entrepreneurship includes two aspects, namely, innovative education and entrepreneurship education. Innovative education stresses on ideological upgrading and theoretical innovation, while entrepreneurship education stresses on the whole practical process of innovative content landing. The basic thinking and theoretical methods of innovation can be improved by offering courses such as "Thinking and Methods in Scientific Research", "Creativity" and "Frontier Technology Series Report". Entrepreneurship education is mainly through the "innovation and entrepreneurship education foundation" course to establish students' basic cognitive concept, but also through participation in the innovation and entrepreneurship competitions to deepen the understanding and experience.

The cultivation of collaborative innovation ability emphasizes the whole process of consulting countermeasures, orderly division of labor and cooperation, and integration of wisdom among students. Through setting up cooperative courses such as "curriculum design", "mechanical innovation design", "mechanical innovation experiment" and so on, students are actively guided to apply for and develop innovative projects for college students, to participate in basic scientific research step by step, and to be familiar with reports, papers and patents. In practice, through increasing communication, a good sense of teamwork is established, and the spark of mutual 
consultation and collision of wisdom is formed to form a win-win situation and make it have a good ability of cooperation and innovation.

Discipline integration education aims to enable students to have a basic understanding of all related aspects of knowledge, to consider problems from multiple perspectives, and to lay a good foundation for students to solve complex engineering problems. For mechanical majors, basic information technology and computer technology courses, engineering economics courses, electrical, electronic and signal processing related basic courses and basic solid and fluid mechanics courses can be offered, forming a machine-centered, multi-directional extension of an organic comprehensive system. In practice, the whole life cycle design and development courses, such as CDIO, graduation design, are often intensive training.

From the perspective of employment-oriented and adapting to the new economy, mechanical graduates should have the following abilities:

1) Drawing ability: The basic skills of drawing can be established by combining the theory and practice of Engineering Graphics Basis, Mechanical Drawing and CAD, Mechanical Drawing and Surveying and Mapping, and the teaching of three-dimensional drawing such as Solidworks will be offered in the following years, which will open the first door to the field of Engineering technology.

2) Design ability: Through basic and core professional and technical courses, as well as curriculum design, comprehensive design and other practical training, to cultivate students' design ability of products or systems.

3) Computing and development ability: through the knowledge of advanced mathematics, economics, the idea of computational language programming, and the use of commercial software, to achieve the basic solution and calculation of design problems, as well as the economic budget of the design scheme, to carry out a reasonable evaluation of the design scheme.

4) Informatization capability: including the ability to use basic information technology and tools, as well as the integration of information elements in design issues, so that the design and development of the program with information characteristics. This ability mainly through information-based classroom teaching to enhance students' basic information literacy, through the practice of innovative training projects to promote students' information-based thinking and information application.

\section{Summary}

On June 2, 2016, China became a full member of the 18th Washington Agreement, and the internationalization of engineering education has taken an important step. With the further internationalization of Engineering education, great changes will take place in the training mode of applied professionals in China's higher education. It will become a universal "feature" of engineering specialty to grasp the application and adapt to the new economy. This paper makes a preliminary study on the training mode of applied first-class professionals, and sums up the following suggestions:

1) the cultivation of engineering applied talents should attach importance to the guidance and cultivation of engineering ideology and consciousness.

2) Innovation and entrepreneurship education should be integrated into the general curriculum system of higher education, so that innovation and entrepreneurship become a universal ideology.

3) According to the new economic form of different majors, we should construct a reasonable application-oriented and innovative curriculum system, highlight the multi-disciplinary integration education, collaborative innovation education and information-based education, and face the cultivation of the ability to solve miscellaneous engineering problems.

\section{Acknowledgement}

This research was financially supported by the research project on teaching reform of higher education in Shaanxi(Grant NO. 17BY133). 


\section{References}

[1] D. L. Zhang, Six problems in the construction of new engineering, Guangming Daily, edition $13^{\text {th }}, 2017$

[2] X. D. Liu, M. Z. Shi, F. R. Chen, et. al., Enrich the connotation, highlight the characteristics, perfect the training plan and improve the quality of personnel training--- Experience in Revision of Specialty Training Program for Undergraduates of Material Forming and Control Engineering, Journal of Inner Mongolia University of Technology, vol. 15(2), pp. 96-99, 2006

[3] H. C. Wang, J. Y. Liu, Core and difficulty of innovation and entrepreneurship education in universities and breakthroughs, China's higher education, vol. (13), pp. 61-63, 2017

[4] W. Y. Sheng, H. J. Zhen, Exploration and practice of the characteristics of talent training in local universities, Teaching in Chinese universities, vol. (6), pp. 56-57, 2009

[5] Y. H. HU, X. L. Song, G. Z. Qiu, et. al., Innovation and Practice in the Training Model of International First-class Disciplines and Cultivation of Top-notch Compound Talents--Multidisciplinary Interdisciplinary Mineral Processing Talents, Research on Higher Engineering Education, vol. (2), pp. 112-117, 2011 